http://dx.doi.org/10.1590/0370-44672018720040

\section{Guilherme Manfredini Bueno ${ }^{1,3}$ \\ Eduardo Rimolo Carneiro ${ }^{1,4}$ \\ Ana Claudia Lemos Ramão ${ }^{1,5}$ \\ Giulianna Ody Piva ${ }^{1,6}$ \\ Bernardo Fonseca Tutikian ${ }^{2,7}$}

'Universidade do Vale do Rio dos Sinos - Unisinos, Programa de Pós-Graduação em Engenharia Civil

(PPGEC), São Leopoldo - Rio Grande do Sul - Brasil.

${ }^{2}$ Universidade do Vale do Rio dos Sinos - Unisinos, Programa de Pós-Graduação em Engenharia Civil (PPGEC), Programa de Pós-Graduação em

Arquitetura e Urbanismo,

São Leopoldo - Rio Grande do Sul - Brasil.

E-mails.: ${ }^{3}$ guilherme-m-b@hotmail.com,

${ }^{4}$ eduardorimolocarneiro@gmail.com,

5ana.ramao@gmail.com, ${ }^{6}$ arq.giulianna@gmail.com, ’bftutikian@unisinos.br

\title{
Evaluation of reinforced
} concrete structural durability in the post-occupation phase - A case study in Novo Hamburgo/RS

\begin{abstract}
Researches on building performance have been developed over time. The Brazilian Performance Standard - NBR 15575 - deals with the issues of durability applied to residential buildings, establishing criteria and parameters to classify the systems into minimum, intermediate and higher performance levels. In relation to the service life, studies are also associated with the building's structural durability, in which the technical specifications and quality of materials, construction systems, building process, use and maintenance of the building are important factors for better performance. In order to evaluate the structural durability over the years, a case study was conducted in a building designed to meet the higher level established in the Brazilian Performance Standard, with service life of 75 years in the structural project, through the non-destructive surface hardness of concrete test by using a Schmidt hammer and semi-destructive carbonation tests. The superficial hardness test was conducted on a concrete column following the procedures of NBR 7584, while the carbonation samples were collected in 3 concrete columns in which a phenolphthalein solution was sprayed to observe the alkalinity of the samples. For all tests, three different heights were considered. The concrete testing hammer indicated an average surface hardness of approximately $50 \mathrm{MPa}$, and for carbonation tests, it was noted that the concrete was not carbonated at a depth of $5 \mathrm{~mm}$. So, the criteria of service life could be considered attended.
\end{abstract}

Keywords: building performance, design service life, durability, surface hardness, carbonation.

mechanisms of liquids and gases in the pores of the composite (Medeiros; Andrade; Helene, 2011).

The concrete structural durability is an issue of high concern in the construction sector in regard to safety, economy, and sustainability. To perform well in relation to structural durability, it is necessary to employ appropriate materials for a particular environmental condition in which the building is exposed to in the design and its implementation (Possan, 2010). According reinforced concrete structural durability explain in large part the penetration 
to Neville and Brooks (2013), the concrete permeability has a direct relation to its durability. The less porous the concrete, the higher its strength and durability, since the smaller air void content hinders the penetration of water and harmful agents.

The condition that most affects the durability is corrosion caused by carbonation and chloride penetration. Different factors can influence the process, such as the concentration of aggressive agents and the relative humidity in the structure's pores. The place where the structure was built and the properties of the hardened concrete influence on the speed and depth of carbonation (Figueiredo, 2005; Isaia, 2011; Salvoldi, Beushausen; Alexander, 2015). Neves et al. (2015) analyzed the concrete compressive strength in relation to the carbonation rates. Their results indicate that strength suffers reduction with increased rates. The key factor for this correlation is revealed in the analysis of the material's permeability, where more pores represent a greater vulnerability to the action of gases like $\mathrm{CO}_{2}$.

The fact that the reinforcement corrosion rate in carbonated concrete is controlled by the electrolytic resistance of materials, allows this to be reduced to negligible levels if the concrete is held waterproof (Gonzalez, Algaba, Andrade, 1980; Glass, Page, Short, 1991). The covering is responsible for preventing the ingress of moisture (Seneviratne, Sergi, Page, 2000).

The building service life is marked by the parts of the building that do not require maintenance, namely, structural elements, column, beams, and foundations (ABNT, 2013), and is defined by the time during which the system must meet the minimum performance specifications (John; Agopyan; Sjöström, 2002). For

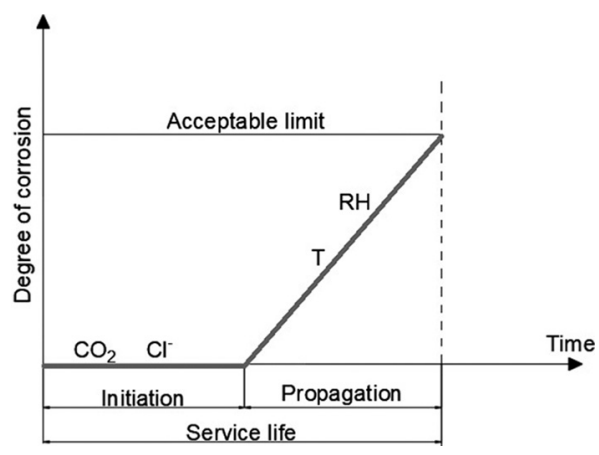

The performance standard provides 3 periods relating to the service life of structural concrete projects, as shown in Table. 1.

\begin{tabular}{c|c|c|c}
\multirow{2}{*}{ System } & \multicolumn{3}{|c}{ Design service life (years) } \\
\cline { 2 - 4 } & Minimum & Intermediate & Higher \\
\hline Structure & $\geq 50$ & $\geq 63$ & $\geq 75$ \\
\hline
\end{tabular}

The design conditions are determined by the exposure environment conditions and its aggressiveness. According to NBR 6118 (ABNT, 2014), urban environments lead classification II - Moderate with little risk of structural deterioration.

Over time, concrete structures tend to show signs of deterioration. Among the various causes, the carbonation is probably the most common in urban areas with a high concentration of carbon dioxide $\left(\mathrm{CO}_{2}\right)$ in the atmosphere. Concrete is a porous material that allows the pen- etration of various substances through its interconnected pore capillaries. After penetrating the concrete pores, the $\mathrm{CO}_{2}$ from the atmosphere reacts with calcium hydroxide $(\mathrm{CH})$. The reaction causes the carbonation, and the consequent loss of reinforcement protection against corrosion because the alkalinity of the composite diminishes drastically to less than 9. So, the steel reinforcement corrodes and loses the initial resistance, leading to pathological manifestations, such as cracks and breaks in the structure (ABNT, 2014; concrete structures, the serviceability limit state for service life is at least 50 years (ABNT, 2013). Less durable structures end up consuming a larger amount of raw material, produce pollutants, consume energy and generate spending on repairs and maintenance (Medeiros; Andrade; Helene, 2011).

Among the building life cycle stages, the phase of use and operation is the longest. Maintenance activities should be preventive rather than corrective (Maia, 2016). So, maintenance plans, contained in the user manual, aid in the maintenance of the building features, avoiding renovations and demolitions and increasing the service life (Rodrigues; Rocha, 2015).

The end of service life of a reinforced concrete structure is set to the end of the period of initiation and the beginning of critical propagation mechanism as shown in Fig. 1 (Tuuti, 1982).

Figure 1

The sequence of initiation and propagation in reinforced concrete (Tuuti, 1982).

Table 1

Minimum, intermediate and higher design service life. Source: Adapted from NBR 15575 (ABNT, 2013).

Duprat; Vu; Sellier, 2014; Mehta; Monteiro, 2014; Possan, 2010; Khunthongkeaw; Tangtermsirikul; Leelawat, 2006; Ahmed, Benharzallah, 2017), decreasing the strength of the structure (YOON et al., 2000) and the bond behavior between the reinforcement and the concrete (Grassl and Davies, 2011).

Carbon dioxide penetrates in the unsaturated concrete pores, dissolves and reacts with hydrated compounds according to Eq. 1 and 2, relating to the chemical balance (Duprat, Vu, Sellier, 2014):

$$
\begin{gathered}
\mathrm{Ca}(\mathrm{OH})_{2}+\mathrm{CO}_{2} \rightarrow \mathrm{CaCO}_{3}+\mathrm{H}_{2} \mathrm{O} \\
3 \mathrm{CaO}-2 \mathrm{SiO}_{2}-3 \mathrm{H}_{2} \mathrm{O}+3 \mathrm{H}_{2} \mathrm{CO}_{3} \rightarrow 3 \mathrm{CaCO}_{3}+3 \mathrm{H}_{2} \mathrm{O}+2 \mathrm{SiO}_{2}-
\end{gathered}
$$

The ingress of harmful agents from the environment can be avoided by the use of impermeable membranes or coatings. 
For this purpose, a treatment capable of reducing the diffusion of gases and moisture inside the concrete must be applied to the surface. Analyzing the depth of carbonation in specimens, Ibrahim et al. (1999) have identified that in concretes with treated surface, the carbonation was significantly smaller than in exposed concrete. The results indicate a reduction of up to $50 \%$ between the systems.

The performance of concrete structures is established through a concrete testing hammer or superficial hardness testing (Malhotra and Carino, 2004). As the carbonation progresses, the surface hardness of concrete tends to increase because the pores in the hardened cement paste reduce as much as the density increases (Sahuinco, 2011). Naik and Singh (1998) identified that the layer of passive protection of the steel inside the concrete can be destroyed, starting a process of

\section{Characteristics of the building}

A residential building located in Novo Hamburgo, RS, Brazil inaugurated in June 2016 was analyzed. Built on a site of $3,074.12 \mathrm{~m}^{2}$, the vertical multi-family condominium has a total area of $17,993.63 \mathrm{~m}^{2}$ with 26 floors divided into: 3 basements, a ground floor, a mezzanine, 16 typical floors, 04 duplex floors and a rooftop.

The apartments are distributed in 4 per floor, with double access hall, three lifts and a fire escape, totaling 72 housing units of which there are: 32 apartments of 3 bedrooms with $115.58 \mathrm{~m}^{2}$ floor area; 32 apartments of 2 bedrooms with

\section{Method}

To achieve the goal of the study, the concrete surface hardness and the carbonation thickness of the concrete structures were analyzed through non-destructive and semi-destructive tests. With this, it is possible to determine the carbon dioxide diffusion coefficient.

In situ verifications of the building's structural system were made, in addition to carbonation tests. A surface hardness test of the concrete was also carried out, corrosion. However, the carbonation tends to increase the surface density, reducing porosity and consequently its permeability, demonstrating the positive effects of the process on the durability of concrete structures.

The Schmidt hammer is one of the most used techniques to evaluate the surface hardness of concrete (Neville, 2015; El Mir and Nehme, 2017). This method can be used to estimate the concrete uniformity and to detect areas of lower quality within a structure. However, it is not a substitute for the concrete compressive strength tests. The overview of many users of the Schmidt hammer is that the test is useful in the assessment of concrete uniformity and the comparison of different concretes, however it can only be used as an approximate indication of strength in absolute terms (Liu, Sue; Kou, 2009). The goal of the concrete hammer

$94.76 \mathrm{~m}^{2}$ floor area; 8 duplexes with 65.84 $\mathrm{m}^{2}$ on the lower deck plus $96.44 \mathrm{~m}^{2}$ on the upper deck.

The project was developed using a BIM platform, in which the building representations were made in three dimensions (3D). Its differential in relation to common 3D models is the ability to link information to entities and components (Sacks; Radosavljevic; Barak, 2010).

The building has a reinforced concrete structure, using columns, beams and slabs molded both in situ and precast. The external and partition walls were con- test is to find a relationship between surface hardness and compressive strength within an acceptable error (Szilagyi; Borosnyói; Zsigovicset, 2011). According to Cánovas (1988), there may be differences in quality between the concrete used to calibrate the equipment and the concrete to be tested, which causes variations in the results.

The evaluation of existing concrete structures is preferably performed using non-destructive testing methods. However, semi-destructive tests are used for analyzing the carbonation thickness of concrete structures. With this, it is possible to determine the diffusion coefficient of the carbon dioxide.

Thus, this study aims to evaluate the building durability of a post-occupation phase designed to meet the higher level established in the Brazilian Performance Standard NBR 15575 (ABNT, 2013). structed with ceramic blocks coated with prefabricated mortar. The basement walls were built using cast-in-place concrete curtains. For the rooftop, a cast-in-place concrete slab was built.

The concrete compressive strength specified for the structural system was $40 \mathrm{MPa}$. For the concrete mix, Portland IV cement 32 RS was used, with a w/c ratio of 0.55 and a cement consumption of $320 \mathrm{~kg} / \mathrm{m}^{3}$, and also added was a water reducing additive. The thickness assumed to the nominal reinforcement coatings was $30 \mathrm{~mm}$, according to the design. which is a non-destructive method that consists of the impact promoted on the structure surface with a determined kinetic energy, establishing the measures of the force return, through the equipment called Schmidt Hammer (Malhotra and Carino, 2004). In all the tests, measurements were performed at 3 heights: low, intermediate and high.

For surface hardness measurement of the concrete, a column located in the ma- chine room with the same characteristics of the structural system was chosen. With the pacometer (Fig. 2), which has the function of detecting the position and diameter of the metallic reinforcement, as well as the thickness of concrete covering on the reinforcement (Mehta and Monteiro, 2014), it was possible to detect the reinforcements of the column analyzed. The technical specifications of the equipment used in the study can be seen in Table 2 .
Table 2

Characteristics of pacometer used in the study.

\begin{tabular}{c|c} 
Model & D-tect 150 Professional \\
\hline Company & Bosch \\
\hline Maximum detection depth & $150 \mathrm{~mm}$ \\
\hline Power supply & $4 \times 1.5$ V LR6 (AA) \\
\hline
\end{tabular}




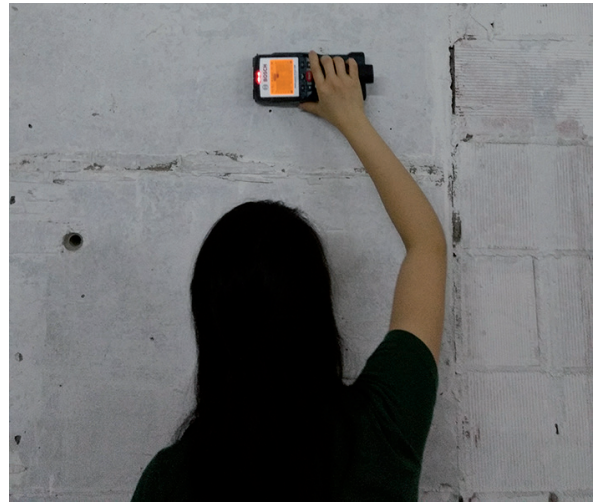

After the verification of the reinforcement thickness cover using the pacometer,

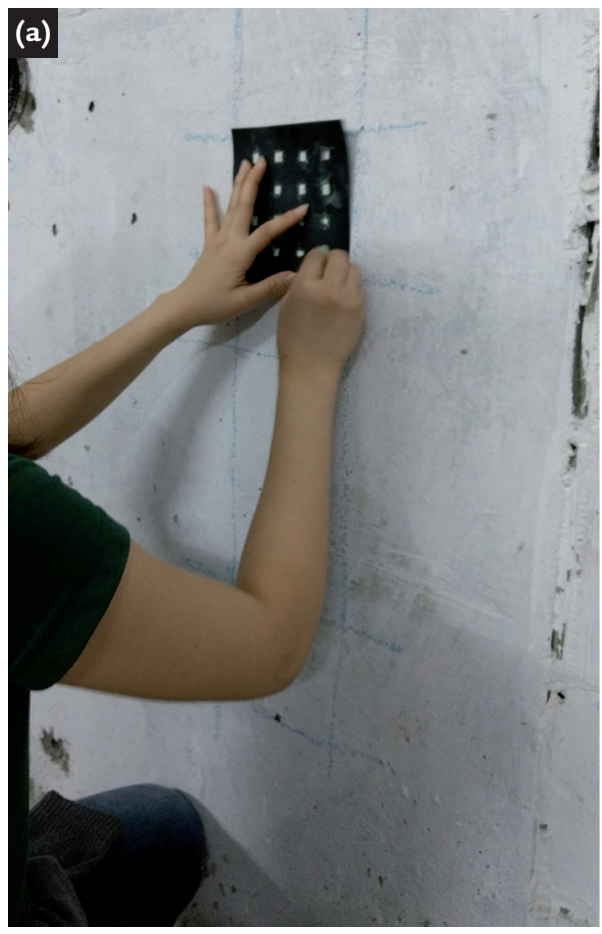

In the hammer test, the measurement of the surface hardness was performed at several nearby points, since the concrete properties can have great variations, even in a localized region (Neville, 2015). Because it is a non-

\begin{tabular}{c|c} 
Model & SilverSchmidt \\
\hline Company & Proceq \\
\hline Impact energy & $2.207 \mathrm{Nm}(\mathrm{N}), 0.735 \mathrm{Nm}(\mathrm{L})$ \\
\hline Compressive strength range & 10 to $100 \mathrm{~N} / \mathrm{mm}^{2}(1 ' 450$ to 14 ' $500 \mathrm{psi})$ \\
\hline
\end{tabular}

The carbonation process is easily measured by the sprinkling of phenolphthalein solution. The mixture should have 1 $\mathrm{g}$ of indicator for each $100 \mathrm{ml}$ of alcohol/ water in a ratio 50:50 (Parrot, 1987). The solution, when applied on the affected material, remains colorless. In non-carbonated with a Schmidt hammer, a concrete surface hardness test was performed (Fig. 3).

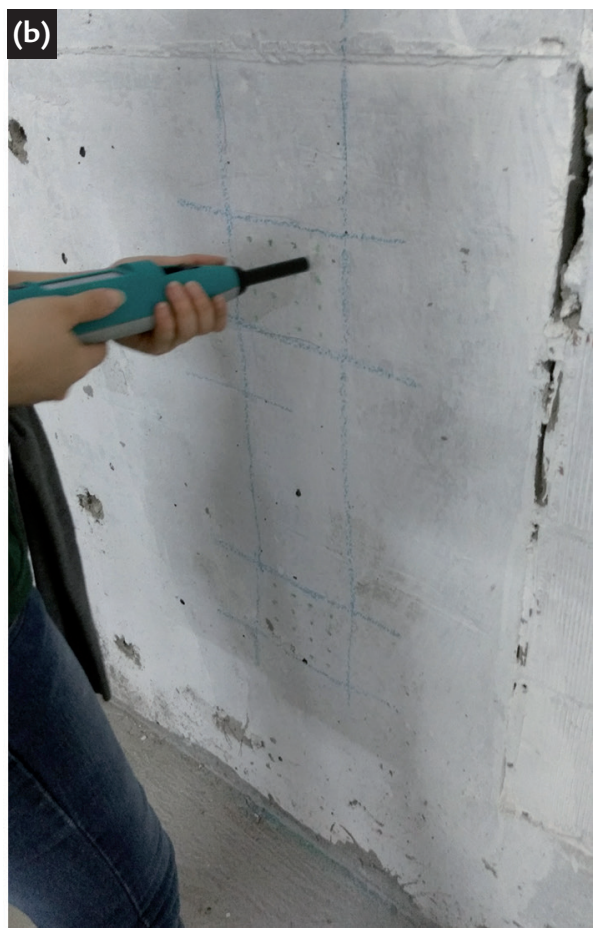

destructive test, it can be accomplished with the structure in use, without causing any injury. The results vary according to the surface conditions and rigidity of the structure, moisture and the carbonation rates (Mehta and Monteiro, 2014).
Figure 2

Placement of the pacometer on the column to detect the reinforcement.
Figure 3

Surface hardness test:

(a) marking the points with the test gauge e (b) placement of the Schmidt hammer.

A total of 16 measurement points were marked using a test gauge, according to the requirements of NBR 7584 (ABNT, 2012). The technical specifications of the Schmidt hammer used in the study can be seen in Table 3 .

Table 3

Characteristics of

Schmidt hammer used in the study.

shown in Fig. 4. In this study, the analyses were performed on the collected dust at an initial depth of $5 \mathrm{~mm}$, and a drill was used to drill the holes. A collector was placed below the drilling point for the deposition of the concrete dust and a phenolphthalein solution was sprayed as shown in Fig. 5. 
Figure 4

Average carbonation

depth representation: (a) mean carbonation depth and (b) maximum carbonation depth (RILEM, 1988).

Figure 5

Collection of the concrete powder for the carbonation test: (a) preparation of the sample collector bag and (b) extraction of the sample.

The coefficient of carbonation $(k)$ was determined by Tuuti model (Eq. 3),

Where: $\mathrm{X}=$ carbonation depth $(\mathrm{mm})$; $\mathrm{k}=$ carbonation ratio $\left(\mathrm{mm} /\right.$ year $\left.^{1} / 2\right)$; $\mathrm{t}=$ exposure time (year).

Where: $e_{c}=$ thickness of the covering reinforcement $(\mathrm{mm}) ; \mathrm{k}=$ carbonation ratio $\left(\mathrm{mm} /\right.$ year $\left.^{1} / 2\right) ; \mathrm{T}=$ time for carbonation to

\section{Results}

After conducting the tests, analyses were made. The measurements made with the pacometer indicated that the reinforce-

Table 4

Surface hardness of concrete measured.

Carbonation tests occurred on three columns of the building. The tests were
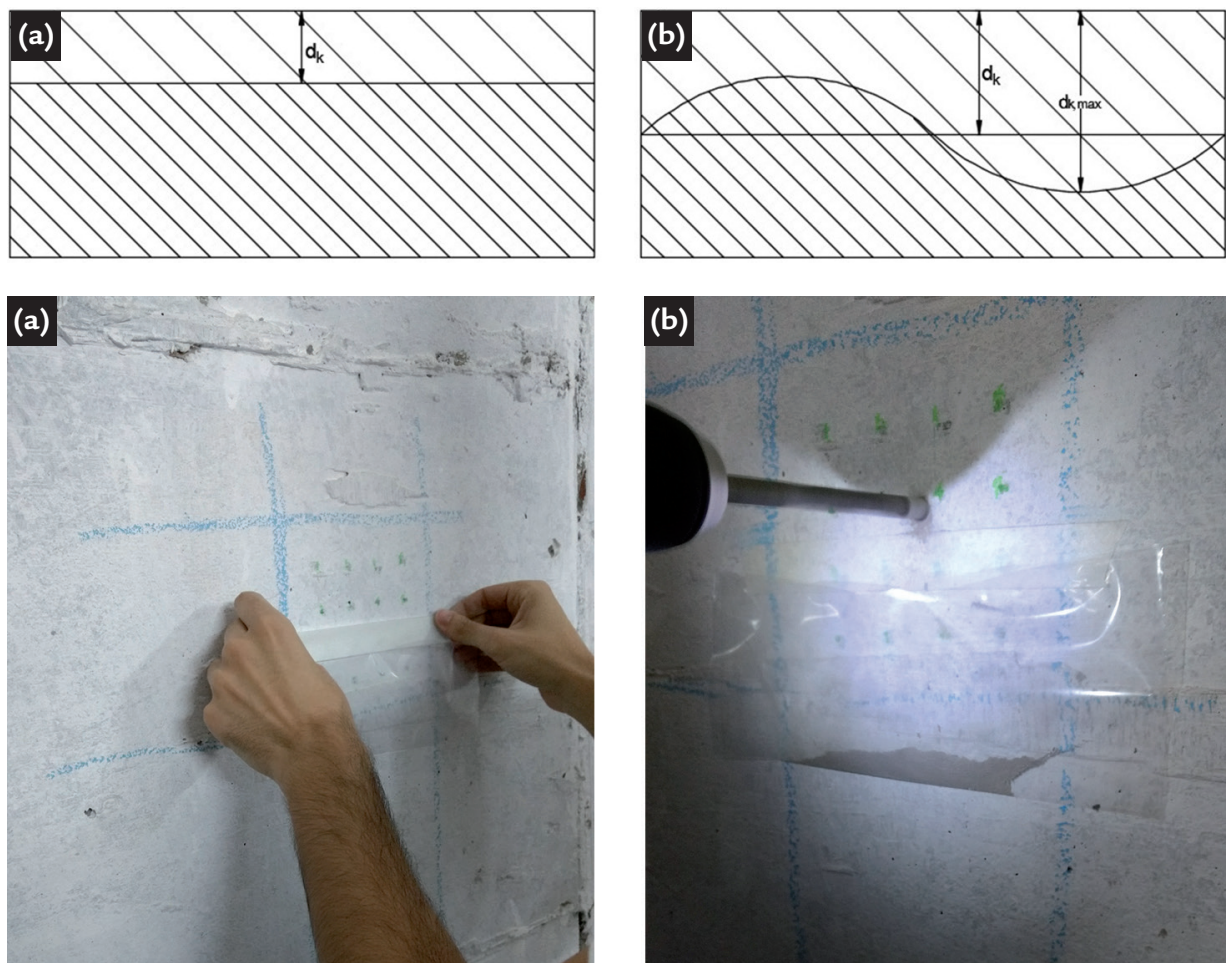

which expresses carbonation thickness $(X)$ as a function of the exposure time

$$
X=k \sqrt{t}
$$

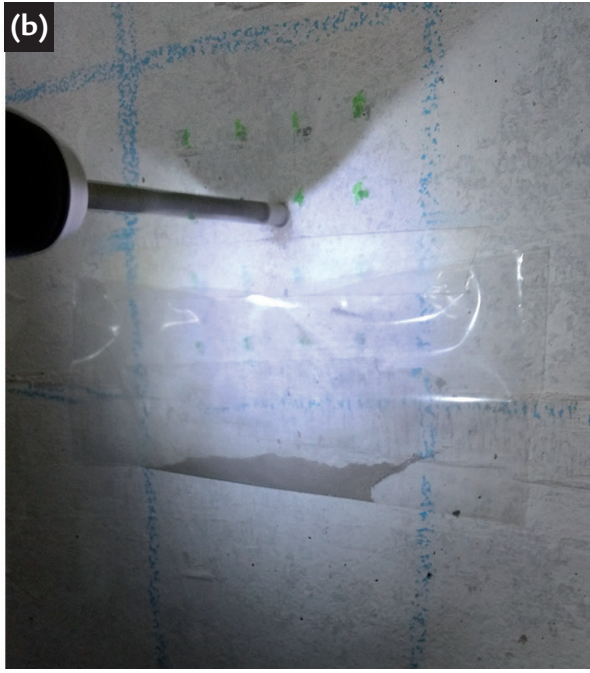

of the structure $(\mathrm{t})$.

(Eq. 3)

From the calculated carbonation ratio $(\mathrm{k})$ and the thickness of the covering reinforcement $\left(e_{c}\right)$, the time for carbon-

$$
\mathrm{e}_{\mathrm{c}}=\mathrm{k} \sqrt{\mathrm{T}}
$$

reach the reinforcement (year).

The time to carbonation to reach the reinforcement $(T)$ was found, so the

$$
\text { VUPres }=T-t
$$

(Eq. 5)

ation to reach the reinforcement $(T)$ was calculated by the Eq. 4 based on Tuuti's model (1982).

(Eq. 4)

residual service life (VUPres) was calculated using Eq. 5.

ment cover was in accordance with the covering specified in the project, i.e. $30 \mathrm{~mm}$. For the concrete surface hardness, the measure-

ments performed with the Schmidt hammer indicated that the average values were close to $50 \mathrm{MPa}$, as indicated in Table 4.

\begin{tabular}{c|c|c|c}
\multirow{2}{*}{ Parameters } & \multicolumn{3}{|c}{ Heights } \\
\cline { 2 - 4 } & Low & Intermediate & High \\
\cline { 2 - 4 } & 48.4 & 51.3 & 54.4 \\
\hline Average [MPa] & 7.4 & 2.8 & 5.6 \\
\hline Standard deviation $[\mathrm{MPa}]$ & & &
\end{tabular}

carried out in the machine room of the top lot, respectively, as shown in Table 5. floor, treatment station and in the parking 


\begin{tabular}{|c|c|c|c|}
\hline Column/Location & Hole & Height & Depth [mm] \\
\hline \multirow{5}{*}{ Machine room } & 1 & low & \multirow{3}{*}{5} \\
\hline & 2 & intermediate & \\
\hline & 3 & intermediate & \\
\hline & 4 & intermediate & 10 \\
\hline & 5 & high & 5 \\
\hline \multirow{3}{*}{ Treatment station } & 6 & low & \multirow{3}{*}{5} \\
\hline & 7 & intermediate & \\
\hline & 8 & high & \\
\hline \multirow{3}{*}{ Parking lot } & 9 & low & \multirow{3}{*}{5} \\
\hline & 10 & intermediate & \\
\hline & 11 & high & \\
\hline
\end{tabular}

On the top floor, the column was tested inside the machine room and without coating, being exposed to gases and moisture. The samples collected in the low and high heights of the column indicated that the concrete was not carbonated to a depth of $5 \mathrm{~mm}$, in accordance with the pinkish color ac-
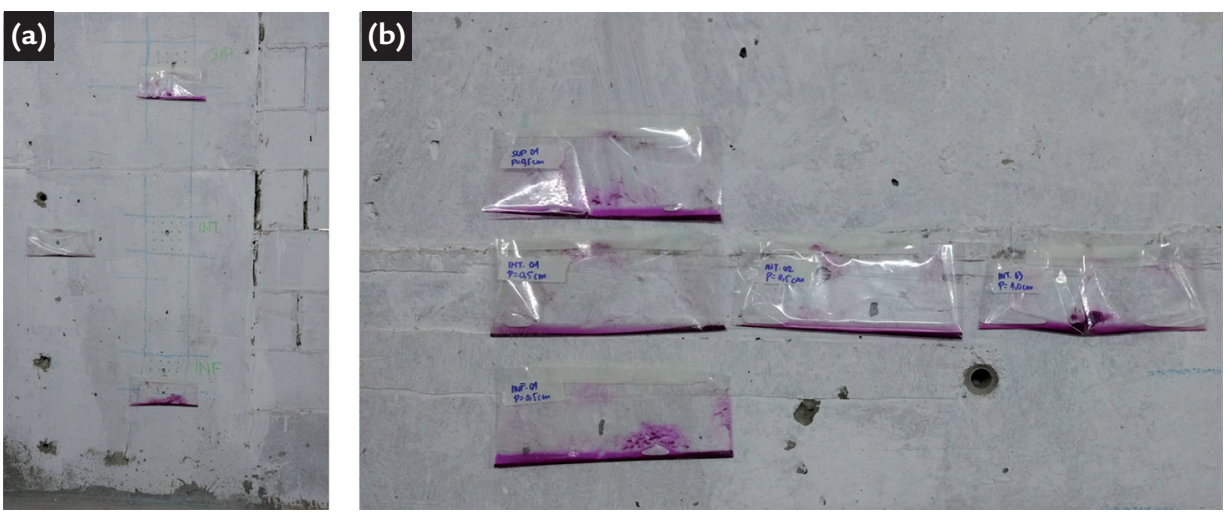

The tests on the column of the treatment station showed similar results to tests in the machine room. Although in
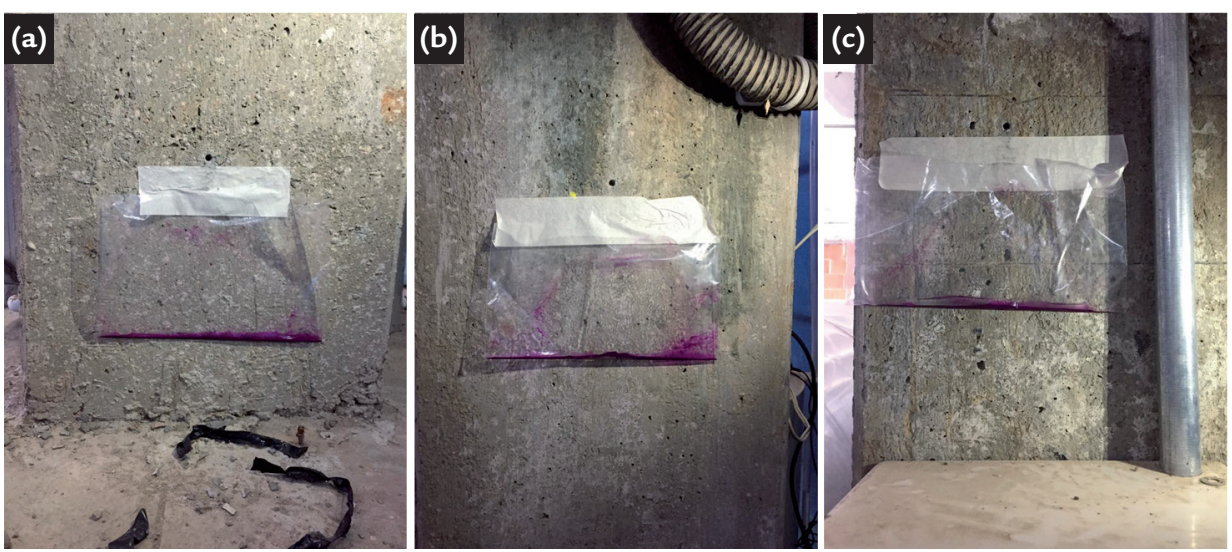

The third column located in the parking lot, as well as the previous ones, has been tested for three heights Fig. 8). In this case, the structure was covered with epoxy paint that provides protec- quired by the sample after the sprinkling of phenolphthalein.

In the intermediate height sample, there was no color change in the first seconds after the sprinkling of phenolphthalein. However, after about 30 seconds, the sample presented the pink coloration characteristic of no carbonation. The

the basement, the column was in similar conditions indoors and without covering. Samples were collected at three heights, tion and waterproofing, avoiding the accumulation of moisture and gases in the three samples showed no carbonation. Although the column environment is concrete pores. At the $5 \mathrm{~mm}$ depth, the

Table 5

Results of tests carried out.

procedure was repeated in the same region of the column to the same depth. The second sample confirmed the result, with the same reaction time. To validate the test, we made a third hole with a $10 \mathrm{~mm}$ depth. The reaction occurred instantly, validating that the concrete was not carbonated, as shown in Fig. 6.

Figure 6

Machine room

column samples: (a) $5 \mathrm{~mm}$ depth samples and (b) all collected samples.

low, intermediate and high (Fig. 7). All samples indicated that the concrete was not carbonated at a $5 \mathrm{~mm}$ depth.

Figure 7

Column samples of the treatment station.

a parking lot susceptible to high levels of carbon dioxide in the air, the results indicate that the cover protection avoids the carbonation process as well as degradation of the system. 
Figure 8

Column samples of the parking lot.

The carbonation ratio $(k)$ was calculated through Eq. 3 for the $5 \mathrm{~mm}$ carbonation depth $(\mathrm{X})$ of the samples tested, and for the 2-year structure exposure time. The carbonation ratio (k) found was $3.5355 \mathrm{~mm} /$ year $1 / 2$. The time for carbonation to reach the reinforcement (T) found through Eq. 4 was 72 years for the $30 \mathrm{~mm}$ thickness of the covering reinforcement $\left(e_{c}\right)$.

\section{Conclusions}

The present study addressed the building durability and design service life from the point of view of reinforced concrete structures from the analysis of carbonation and surface hardness. The evaluation reinforced concrete structural durability in the post-occupation phase using non-destructive and semidestructive tests is essential to determine the residual service life, as well as to ensure the maintainability of the building. Having identified the characteristics and the current state of the structure, the properties meet the design requirements

\section{Acknowledgments}

The authors would like to thank Performance and Civil Construction

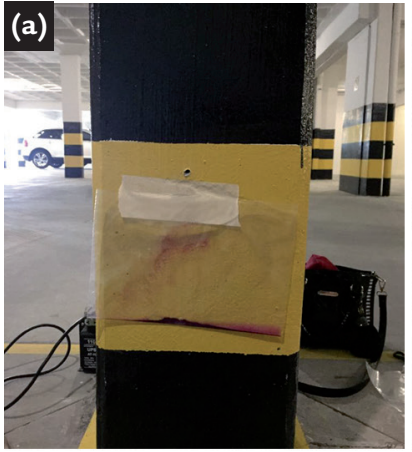

Low



Intermediate

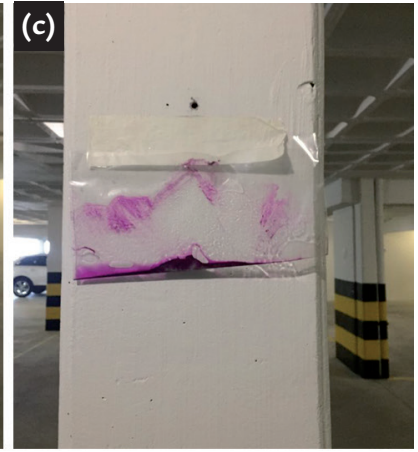

High
From this value, it was possible to estimate the residual service life (VUPres), which is the subtraction between the time for carbonation $(T)$ and the time of exposure ( $\mathrm{t}$ ) expressed in Eq. 5 , resulting in 70 years. For the analyses with $5 \mathrm{~mm}$ depth (RILEM, 1988), the results do not indicate the direct compliance of the 75-year project estimate, although it does not show signs of carbonation.

No tests were performed on the concrete compressive strength of the columns studied. The literature indicates that, for high performance concretes, such as the building object of this study, the carbonation coefficient is $2 \mathrm{~mm} /$ year $1 / 2$ (Ekolu, 2018). This indicates that at two years of exposure, the carbonation depth would be close to $3 \mathrm{~mm}$. for both resistance as to permeability and carbonation resistance.

Attendance at the higher level of Performance Standard - NBR 15575 has not been proven. However, analyses at lower depths of $2 \mathrm{~mm}$ and $3 \mathrm{~mm}$ may be carried out to verify the results. The study was carried out following the recommendations of literature that uses an average assay depth of $5 \mathrm{~mm}$. If depths smaller than $5 \mathrm{~mm}$ were measured, the VUPres should meet the higher level.

It is important to prevent carbonation through coatings and paintings that waterproof the surface and prevent the penetration of moisture and harmful gases and chlorides. This is to avoid the loss of reinforcement protection and its subsequent corrosion. The performance over the service life of the building depends on the decisions and actions taken from the stage of design and construction, as well as during use and occupation stage. As the concrete is a material that undergoes change in its properties over the years, it is important to monitor it. The quality of concrete and reinforcement can be verified even after the implementation phase.
Technological Institute (itt Performance)/ UNISINOS for their support with the equipments used in this study.

\section{References}

AHMED, M., BENHARZALLAH, K. Effect of the carbonatation and the type of cement (cem I, cem II) on the ductility and the compressive strength of concrete. Construction and Building Materials, v. 148, p. 874-886, 2017.

ASSOCIAÇÃO BRASILEIRA DE NORMAS TÉCNICAS (ABNT). NBR 6118: Projeto de estruturas de concreto. Rio de Janeiro, 2014.

ASSOCIAÇÃO BRASILEIRA DE NORMAS TÉCNICAS (ABNT). NBR 7584: Concreto endurecido - Avaliação da dureza superficial pelo esclerômetro de reflexão. Rio de Janeiro, 2012.

ASSOCIAÇÃO BRASILEIRA DE NORMAS TÉCNICAS (ABNT). NBR 15575: Edificações Habitacionais - Desempenho. Parte 1: Requisitos gerais. Rio de Janeiro, 2013.

CÁNOVAS, M. F. Patologia e terapia do concreto armado. São Paulo: PINI, 1988. DUPRAT, F., VU, N. T., SELLIER, A. Accelerated carbonation tests for the pro- 
babilistic prediction of the durability of concrete structures. Construction and Building Materials, v. 66, p. 597-605, 2014.

EKOLU, S. O. Model for practical prediction of natural carbonation in reinforced concrete: Part 1-formulation. Cement and Concrete Composites, v. 86, p. 40-56, 2018.

EL MIR, A., NEHME, S. G. Repeatability of the rebound surface hardness of concrete with alteration of concrete parameters. Construction and Building Materials, v.131, p.317-326, 2017.

FIGUEIREDO, E. P. Efeitos da carbonatação e de cloretos no concreto. São Paulo: IBRACON, 2005, v.1.

GLASS, G. K., PAGE, C. L., SHORT, N. R. Factors affecting the corrosion rate of steel in carbonated mortars. Corros Sci., v. 32, p.1283-94, 1991.

GONZALEZ, J. A., ALGABA, S., ANDRADE, C. Corrosion of reinforcing bars in carbonated concrete. Br Corros J., v.15, p.135-9, 1980

GRASSL, P., DAVIES, T. Lattice modelling of corrosion induced cracking and bond in reinforced concrete. Cement and Concrete Composites, v.33, n. 9, p.918-924, 2011.

IBRAHIM, M., AL-GAHTANI, A. S., MASLEHUDDIN, M., DAKHIL, F. H. Use of surface treatment materials to improve concrete durability. Journal of Materials in Civil Engineering, v. 11, n.1, 1999.

INTERNATIONAL Union of Laboratories and Experts in Construction Materials, Systems and Structures (RILEM). CPC-18. Measurement of Hardened Concrete Carbonation Depth. Paris, France, 1988.

ISAIA, Geraldo Cechella. Concreto: ciência e tecnologia. São Paulo: IBRACON, 2011.

JOHN, V. M., AGOPYAN, V., SJÖSTRÖM, C. Durability in the built environment and sustainability in developing countries. INTERNATIONAL CONFERENCE : DURABILITY OF BUILDING MATERIALS AND COMPONENT, 9. Brisbane, v.9, p. 1-7, 2002. (9DBMC).

KHALIL, E. A. B., ANWA, M. Carbonation of ternary cementitious concrete systems containing flyash and silica fume. Water Science, v. 29, p. 36-44, 2015.

KHUNTHONGKEAW, J., TANGTERMSIRIKUL, S., LEELAWAT, T. A study on carbonation depth prediction for fly ash concrete. Construction and Building Materials, v. 20, n. 9, p. 744-753, 2006.

LIU, J. C., SUE, M. L., KOU, C. H. Estimating the strength of concrete using surface rebound value and design parameters of concrete material. Tamkang Journal of Science and Engineering, v. 12, n. 1, p. 1-7, 2009.

MAIA, B. L. Análise do fluxo de informações no processo de manutenção predial apoiada em BIM: estudo de caso em coberturas. Curitiba: Programa de Pós-Graduação em Engenharia de Construção Civil, Universidade Federal do Paraná, 2016. 101p. (Dissertação de Mestrado em Engenharia de Construção Civil).

MALHOTRA, V. M., CARINO, N. J. Handbook on nondestructive testing of concrete. (2. ed). CRC Press, 2004. 392p.

MEDEIROS, M. H. F., ANDRADE, J. J. de O., HELENE, P. Durabilidade e vida útil das estruturas de concreto. Concreto: ciência e tecnologia, v. 1, p. 773-808, 2011.

MEHTA, P. K., MONTEIRO, P. J. M. Concrete: microstructure, properties, and materials. (4th ed.). AccessEngineering, 2014.

NAIK, T.R., SINGH, S.S. Fly ash generation and utilization - an overview. IN: SURI, A.K., HARAPANAHALLI, A.B. (Eds.). Recent trends in fly ash utilization. New Delhi, India: SOFEM Publisher, 1998. p. 1-25.

NEVES, R., DA FONSECA, B. S., BRANCO, F., DE BRITO, CASTELA, A., MONTEMOR, M F. Assessing concrete carbonation resistance through air permeability measurements. Construction and Building Materials, v. 82, p. 304-309, 2015.

NEVILLE, A. M. Propriedades do concreto. (5.ed). Bookman Editora, 2015. 912p.

NEVILLE, A. M., BROOKS J. J. Tecnologia do concreto. (2. ed.). Porto Alegre: Bookman, 2013.

POSSAN, E. Modelagem da carbonatação e previsão de vida útil de estruturas de concreto em ambiente urbano. Porto Alegre: Programa de Pós-graduação em Engenharia Civil, Universidade Federal do Rio Grande do Sul, 2010. 265p. (Tese de Doutorado em Engenharia).

Received: 9 March 2018 - Accepted: 7 August 2018.

(c) BY All content of the journal, except where identified, is licensed under a Creative Commons attribution-type BY. 